Maria Helena Setsuko Morita ${ }^{\top}$ MÔNICA LóPEZ VÁZqUEZ' LÚCia MitSUKo Yamano JORGE DA SIIVA KAWANO ${ }^{2}$ TAINÁ MOSCA ${ }^{3}$ Wilma Carvalho Neves Forte ${ }^{3}$

Original Article

Keywords

Puerperium Neutrophils/physiology Immune response

Palavras-chave Período pós-parto Neutrófilos/fisiologia Resposta imunológica

\title{
Functional activity of neutrophilic polymorphonuclear leukocytes in the first five days postpartum
}

\author{
A tividade funcional de leucócitos polimorfonucleares \\ neutrofílicos nos primeiros cinco dias após o parto
}

Abstract

PURPOSE: To assess the chemotactic activity and phagocytic response of neutrophilic polymorphonuclear leukocytes among women in the first five days postpartum. METHODS: A prospective, cross-sectional clinicallaboratory study was conducted. Data of 31 postpartum women during the first five days after vaginal delivery were compared with those of 24 healthy nonpregnant non-postpartum women matched for age. The inclusion criteria were postpartum, clinically and obstetrically healthy women; vaginal delivery, singleton pregnancy carried to term; non-hypertensive, hyperglycemic, allergic, malnourished or with autoimmune or neoplastic diseases; not having received vaccines or blood products in the last three months. The Control Group was chosen according to the same inclusion criteria but involving non-pregnant non-postpartum women. The chemotactic activity of neutrophilic polymorphonuclear leukocytes was assessed by determining the distance from directed migration to bacterial lipopolysaccharide, in three Boyden chamber assays. The phagocytic response was identified by assessing the Zymosan particles' ingestion in three assays carried out in Leighton tubes. The Student's ttest was used in the statistical analysis, adopting a 5\% level of significance. RESULTS: The chemotactic activity of neutrophilic polymorphonuclear leukocytes from postpartum women in the presence of homologous (73.2 \pm 6.9 ) and autologous (78.6 1 13.9) sera showed a significant increase compared to the values

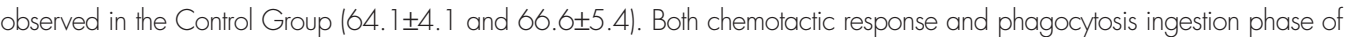
neutrophilic polymorphonuclear leukocytes were significantly increased $(p<0.05$ ) in postpartum women compared to healthy non-pregnant and non-postpartum women. CONCLUSION: There was an increase in the chemotactic activity and phagocytic response of neutrophilic polymorphonuclear leukocytes during the first five days after vaginal delivery in women.

\section{Resumo}

OBJETIVO: Avaliar a atividade quimiotática e a resposta fagocitária dos leucócitos polimorfonucleares neutrofilicos entre puérperas nos cinco primeiros dias após o parto. MÉTODOS: Um estudo clínicolaboratorial prospectivo e transversal foi realizado. Dados de 31 puérperas nos cinco primeiros dias após o parto vaginal foram comparados aos de 24 mulheres saudáveis não gestantes e não puérperas, por meio da idade. Os critérios de inclusão foram puérperas clínica e obstetricamente saudáveis; parto vaginal; gestação de feto único a termo; não hipertensas, hiperglicêmicas, alérgicas ou desnutridas ou portadoras de doenças autoimunes ou neoplasias; sem terem recebido vacinas ou hemoderivados nos últimos três meses. $\bigcirc$ Grupo Controle foi selecionado utilizando-se os mesmos critérios, mas com mulheres não gestantes e não puérperas. A atividade quimiotática por leucócitos polimorfonucleares neutrofilicos foi avaliada determinando-se a distância da migração dirigida ao lipopolissacarídeo bacteriano em três ensaios utilizando-se câmaras de Boyden. A resposta fagocitária foi identificada por meio da ingestão de partículas de zymosan em três ensaios, que foram realizados em tubos de Leighton. Na análise estatística, empregou-se o teste t de Student, adotando-se o nível de significância de 5\%. RESULTADOS: A atividade quimiotática dos leucócitos polimorfonucleares neutrofilicos de mulheres no pós-parto, na presença de soro homólogo $(73,2 \pm 6,9)$ e autólogo $(78,6 \pm 13,9)$, mostrou diferença significante quando comparada aos valores observados no Grupo Controle $(64,1 \pm 4,1$ e 66,6 6 5,4). A resposta quimiotática e a etapa de ingestão da fagocitose por leucócitos polimorfonucleares neutrofilicos apresentaram acréscimos expressivos $(p<0,05)$ em puérperas ao compararem-se aos valores de mulheres saudáveis não gestantes e não puérperas. CONCLUSÃO: Houve um aumento da atividade quimiotática e da resposta fagocitária por leucócitos polimorfonucleares neutrofilicos nos primeiros cinco dias após parto vaginal nas mulheres.

Correspondence

Wilma Carvalho Neves Forte Rua Cesário Motta J., 112 - Vila Buarque Zip Code: $01221-020$ São Paulo (SP), Brazil

Received $01 / 07 / 2015$

Accepted with modifications $13 / 08 / 2015$
Immunology Discipline of the Pathological Sciences Department and Obstetrics and Gynecology Department, Faculdade de Ciências Médicas, Santa Casa de Misericórdia de São Paulo - São Paulo (SP), Brazil.

Obstetrics and Gynecology Department, Faculdade de Ciências Médicas, Santa Casa de Misericórdia de São Paulo - São Paulo (SP), Brazil.

2Faculdade de Ciências Médicas, Santa Casa de Misericórdia de São Paulo - São Paulo (SP), Brazil.

${ }^{3}$ mmmunology Discipline, Pathological Sciences Department, Faculdade de Ciências Médicas, Santa Casa de Misericórdia de São Paulo - São Paulo (SP), Brazil.

Conflict of interests: none. 
Introduction

Postpartum period is defined as the time in the pregnancy-postpartum cycle during which the mother's organism returns to its pre-pregnancy state. The beginning of this phase is marked by the expulsion of the placenta and ovular membranes. Its exact end-point is controversial, but it is often considered to be six to eight weeks after childbirth ${ }^{1}$.

The immune system adaptation is crucial during pregnancy to ensure that the genetic material of paternal origin expressed by the embryo will not be rejected. Hormonal factors at pregnancy and postpartum promote changes in the immune response.

Regarding adaptive immunity, studies are discrepant. Some authors have described return of total peripheral blood lymphocytes to pre-pregnancy levels during the first few weeks postpartum ${ }^{2}$; whereas others have observed this recovery at three to nine months postpartum ${ }^{3-5}$; or other researchers even failed to notice any alteration in $\mathrm{T}$ and $\mathrm{B}$-lymphocytes from the third trimester of pregnancy to the fifth month postpartum ${ }^{6,7}$. Another study showed an increase in the number of lymphocytes and immunoglobulin concentration in the first four months postpartum, particularly CD $3+$ cells and $\mathrm{IgG}^{8}$. Studies are also controversial on quantifications of CD8 + cells, reporting decreased ${ }^{1}$, increased ${ }^{7}$ and unaltered ${ }^{9}$ counts. In another research involving 51 postpartum women four months after childbirth, stable values were observed for CD $4+C D 45 \mathrm{RA}$ cells, increased ones for CD $4+C D 29$, and decreased ones for $\mathrm{CD} 8$ + as compared to normal values for non-postpartum women ${ }^{10}$. As to serum immunoglobulins, studies have reported unaltered values of $\operatorname{IgG}, \operatorname{Ig} A, \operatorname{Ig} M, \operatorname{IgD}$ and $\mathrm{IgE}$ - and B-lymphocytes — during pregnancy ${ }^{11}$. Other investigators have found a decrease in the levels of antibodies during pregnancy, due to the hemodilution from an increase in volume $e^{12,13}$.

Innate response during the postpartum period has been studied to an even lesser extent. Neutrophilic polymorphonuclear leukocytes (PMN) are the first cells to be recruited in immune response, playing a major role in innate immunity. A quantitative study of phagocytic cells observed decreased chemotaxis and PMN adherence from the second trimester of pregnancy to postpartum ${ }^{14}$.

The key role of functional neutrophilic phagocytes prompted the present study. The aims of this study were to assess the chemotactic activity and phagocytic response of neutrophils in healthy postpartum women following vaginal delivery, in the first five days after childbirth, and to compare these results with those of healthy nonpregnant non-postpartum women matched for age.
Methods

The institution Research Ethics Committee approved the present study under number $033 / 10$. Peripheral blood was collected from participants after their written informed consent, under the same protocol number.

A total of 31 postpartum women, assessed during pregnancy and the first five days postpartum following vaginal delivery, were sequentially selected from a specialized tertiary hospital. The inclusion criteria were: aged between 18 and 40 years; clinically and obstetrically healthy pregnant or postpartum women with normal prenatal laboratory results, vaginal delivery, singleton pregnancy, live fetus, amniorrhexis up to four hours before delivery, term pregnancy according to the New Ballard Score; non-hypertensive, hyperglycemic, allergic, malnourished or with autoimmune or neoplastic diseases; and no vaccines or blood products in the last three months. The Control Group consisted of 24 healthy non-pregnant non-postpartum women aged between 18 and 40 years, initially seen in the institution gynecology outpatient clinic, who were chosen using the same inclusion criteria. The Immunology Laboratory immediately analyzed the peripheral blood samples collected.

For the evaluation of phagocyte activity, neutrophils were separated by spontaneous sedimentation at a temperature of $37^{\circ} \mathrm{C}$, and the mononuclear cells were divided by the Ficoll-Hypaque gradient. For the phagocytic intake assessment, $2 \times 10^{6}$ cells $/ \mathrm{mL}$ were counted, and the three tests were performed in Leighton tubes. In the first tube, phagocytes were incubated with $10^{8}$ particles of zymosan ( $\mathrm{Zy}$ ) per $\mathrm{mL}$; in the second, phagocytes and $\mathrm{Zy}$ at the same concentration were incubated with homologous serum pool $(\mathrm{SH})$; in the third, this was done for phagocytes and Zy with autologous serum (AS). After incubation for two hours under $50 \% \mathrm{CO}_{2}$ at $37^{\circ} \mathrm{C}$, the number of phagocytes that had three or more phagocytic vacuoles, in a fixed number of 200 phagocytes, was counted. Similar tests were used to evaluate chemotactic activity: control (phagocytes); phagocytes incubated with bacterial lipopolysaccharide (LPS) and SH; phagocytes, LPS and SA. Results were assessed according to migration distance that was measured in microns ${ }^{15,16}$. All tests were performed in duplicate, and their average was used.

Statistical analysis was carried out using the Statistical Package for Sciences software, version 11.0. Results followed a normal distribution, with means and standard deviations. Means were compared using Student's $t$-test, adopting a $5 \%$ level of significance (p). The correlation between laboratory quantifications and postpartum time interval before sample collection was assessed using Pearson's correlation coefficient. 
Results

Results of the present study showed that the average time between childbirth and blood sampling was $42.5 \pm 24.8$ hours. The age distribution in the women studied showed no statistically significant differences $(\mathrm{p}=0.05)$ between the means of both groups $(27.4 \pm 5.7$ for postpartum women and 28.8 \pm 6.9 for the Control Group).

PMN chemotactic activity of postpartum women in the presence of homologous (73.2 \pm 6.9$)$ and autologous (78.6 \pm 13.9$)$ sera presented a significant increase compared to the values observed in the Control Group

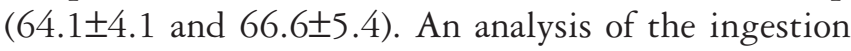
phase of phagocytosis at postpartum group in the presence

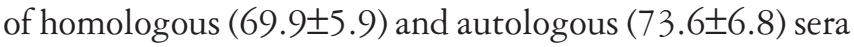
revealed an expressive increase compared to the Control

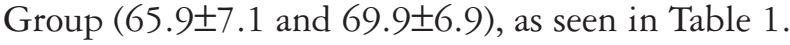

Table 1. Means and standard deviations for chemotactic activity (migration distances expressed in $\mu$ ) and phagocytosis ingestion phase by neutrophilic polymorphonuclear leukocytes (percentage in fixed number of 200 PMN), observed in the group of women in the first five days postpartum (Puerperal Group) and in the group of non-pregnant non-postpartum women matched for age (Control Group)

\begin{tabular}{lcccccc}
\hline Variable/Groups & $\begin{array}{c}\text { Puerperal } \\
\text { Group }\end{array}$ & n & $\begin{array}{c}\text { Control } \\
\text { Group }\end{array}$ & n & p-value \\
\hline Chemotactic activity (LPS+HS) (p) & $73.2 \pm 6.9$ & 31 & $64.1 \pm 4.1$ & 24 & $0.000^{*}$ \\
Chemofactic activity (LPS+AS) (p) & $78.6 \pm 13.9$ & 31 & $66.6 \pm 5.4$ & 24 & $0.000^{*}$ \\
Phagocytic response (Zy+HS) (\%) & $69.9 \pm 5.9$ & 31 & $65.9 \pm 7.1$ & 24 & $0.041^{*}$ \\
Phagocytic response (Zy+AS) (\%) & $73.6 \pm 6.8$ & 31 & $69.9 \pm 6.9$ & 24 & $0.011^{*}$ \\
\hline * significant Student's ftest; HS: homologous serum; AS: autologous serum; \\
LPS: lipopolysaccharide.
\end{tabular}

\section{Discussion}

In this prospective cross-sectional study, there were no differences in age between women from the two groups, a factor that could have influenced the results. Likewise, there was no variance between the test results and the time interval for sample collection, thus showing that the proposed interval of up to five days postpartum was valid. Individuals who were malnourished, had allergies, autoimmune or neoplastic diseases or had been vaccinated were excluded, since these conditions can alter phagocytic activity. Furthermore, subjects who had received blood products within the preceding three months were also removed, because the analysis would have involved the phagocytes received.

In the present study, an increase in chemotactic response and ingestion phase of PMN phagocytosis was observed in the first five days postpartum. Chemotaxis and phagocytosis are among the main activities of $\mathrm{PMN}^{17}$. The investigated neutrophilic phagocytes were separated by spontaneous sedimentation, which alone does not induce chemotactic or phagocytic activity. The serum added for studying PMN functions contains complement system components that, when activated, promote chemotaxis and phagocytosis through phagocytic $\mathrm{C} 3$ and $\mathrm{C} 5$ receptors. Therefore, lipopolysaccharide (LPS) activates C3a and $\mathrm{C} 5 \mathrm{a}$ components and acts as chemotactic factor in the lower compartment of Boyden chamber. These promote the migration of PMN contained in the upper compartment of the chamber. The migration distance can thus be evaluated, since the cells pass through the pores of the Millipore membrane ${ }^{15,16}$.

In an analogous manner, upon activation through Zymosan, the $\mathrm{C} 3 \mathrm{~b}$ and $\mathrm{C} 5 \mathrm{~b}$ components act as opsonins, therefore they coat these particles and allow the ingestion by PMN. The phagocytic vacuoles are then counted among a fixed number of 200 cells. The ingestion phase is an important part of phagocytosis ${ }^{15,16}$.

In the last two decades, few studies on the innate immune response during the puerperium have been conducted, despite the growing interest in immunity. However, most of the available investigations were carried out with animals. Thus, it has been reported that buffaloes with decreased oxidative burst of neutrophils (neutrophil digestion) have a greater tendency to infectious processes during the puerperium ${ }^{12}$. No studies investigating the functional activity of neutrophilic phagocytes in the early postpartum period have been found.

PMN chemotaxis and phagocytosis are necessary activities in the defense against catalase-positive bacteria, especially Staphylococcus aureus ${ }^{17}$. Such bacteria are the etiological agents of abdominal wall infections in caesarean deliveries and also contribute to postpartum endometriosis. The postpartum period may involve physiological alterations in the innate immune response, which are compatible with the defenses required for this period.

Several factors contribute to an increased susceptibility to group A Streptococcus, Staphylococcus aureus, thus causing postpartum sepsis: mode of delivery (vaginal or caesarean), location where labor and delivery occurs, exposure to group A Streptococcus, and immune response ${ }^{18}$. Some bacterial pathogens can evade innate host defenses ${ }^{19}$. Group A Streptococcus uses several virulence factors to evade ingestion by neutrophils in soft tissue infections ${ }^{20,21}$. Upon neutrophilic phagocytosis, group A Streptococcus up-regulates genes involved in tempering oxidative stress, in cell envelope components and virulence factors ${ }^{19,21,22}$. This suggests that group A Streptococcus can effectively respond to different host environments for promoting persistence. For timely defense against bacterial infections by group A Streptococcus, neutrophils must play their role effectively in the postpartum period. Studies have shown an increase in the number of neutrophils in the peripheral 
blood during puerperium, regardless of the infection ${ }^{23}$. It is possible that women in the postpartum period with better protection against group A Streptococcus might not develop infections, such as those caused by bacteria, as may have occurred in this study.

In the present study, postpartum women with vaginal delivery were selected. The results observed for PMN activity were consistent with the available knowledge on childbirth inflammatory response. Proinflammatory cytokines, such as tumor necrosis factors (TNF) and interferon-gamma (IFN- $\gamma$ ), are known to be important for normal labor ${ }^{24}$. Also, both cytokines promote an increase in chemotactic activity and phagocytic PMN response. Cytokines required for normal labor may remain high in early puerperium, and such increased PMN activity may contribute to the immune defense of postpartum women.

Finally, there was an increase in PMN chemotactic activity and phagocytosis during the first five days after vaginal delivery in women.

\section{Acknowledgments}

To the Undergraduate Course of School of Medical Sciences of Santa Casa de São Paulo that granted a scholarship to the first author.

\section{References}

1. Vieira CS, Brito MB, Yazlle ME. [Postpartum contraception]. Rev Bras Ginecol Obstet. 2008;30(9):470-9. Portuguese.

2. Nakamura N, Miyasaki K, Kitano Y, Fujisaki S, Okamura $H$. Suppression of cytotoxic T-lymphocyte activity during human pregnancy. J Reprod Immunol. 1993;23(2): 1 19-30.

3. Baboonian C, Grundy JE, O'Brien PM, Griffiths PD. Responses to mitogenic stimulation of lymphocytes taken during and after pregnancy. FEMS Microbiol Immunol. 1989;1 (4): 199-204.

4. Gehrz R, Christianson W, Linner KM, Conroy MM, McCue SA, Balfour $\mathrm{HH}$ Jr. A longitudinal analysis of lymphocyte proliferative responses to mitogens and antigens during human pregnancy. Am J Obstet Gynecol. 1981;140(6):665-70.

5. Stagnaro-Green A, Roman SH, Conin RH, el-Harazy E, Wallenstein $S$, Davies TF. A prospective study of lymphocyte-initiated immunosuppression in normal pregnancy: evidence of a T-cell etiology for postpartum thyroid dysfunction. J Clin Endocrinol Metab. 1992;74(3):645-53.

6. Birkeland SA, Kristoffersen K. T and B lymphocytes during normal human pregnancy: a longitudinal study. Scand J Immunol. 1979;10(5):415-9.

7. Fiddes TM, O'Reilly DB, Cetrulo CL, Miller W, Rudders R, Osband $M$, et al. Phenotypic and functional evaluation of suppressor cells in normal pregnancy and in chronic aborters. Cell Immunol. 1986;97(2):407-18.

8. Iwatani $Y$, Amino N, Tachi J, Kimura M, Ura I, Mori M, et al. Changes in lymphocyte subsets in normal pregnant and postpartum women: postpartum increase in NK/K (Leu 7) cells. Am J Reprod Immunol Microbiol. 1988;18(2):52-5.

9. Matthiesen L, Berg G, Ernerudh J, Skogh T. Lymphocyte subsets and autoantibodies in pregnancies complicated by placental disorders. Am J Reprod Immunol. 1995;33(1):31-9.

10. Gennaro S, Fehder W, Gallagher P, Miller S, Douglas SD, Campbell DE. Lymphocyte, monocyte, and natural killer cell reference ranges in postpartal women. Clin Diagn Lab Immunol. 1997;4(2): 195-201.

11. Patton PE, Coulam CB, Bergstralh E. The prevalence of autoantibodies in pregnant and nonpregnant women. Am J Obstet Gynecol. $1987 ; 157(6): 1345-50$
12. Jensen $E$, Wood C, Keller-Wood M. The normal increase in adrenal secretion during pregnancy contributes to maternal volume expansion and the fetal homeostasis. J Soc Gynecol Investig. 2002;9(6):362-71.

13. Klein $\mathrm{HH}$, Pich S. [Cardiovascular changes during pregnancy]. Herz. 2003;28(3):173-4. German.

14. Krause PJ, Ingardia CJ, Pontilus LT, Malech HL, LoBello TM, Maderazo EG. Host defense during pregnancy: neutrophil chemotaxis and adherence. Am J Obstet Gynecol. 1987;157(2):274-80.

15. Forte WC, Guardia VC, Mantovani PA, Dionigi PC, Menezes MC. Evaluation of phagocytes in atopic dermatitis. Allergol Immunopathol (Madr). 2009;37(6):302-8.

16. Menezes MC, Malafronte P, Souza JF, Sens YA, Forte WC. Evaluation of neutrophilic activity in patients submitted to kidney transplantation. Ren Fail. 2010;32(4):464-8.

17. Forte WC, Nagoya AM, Carvalho FF Jr, Bruno S. Repeated furunculosis in adult male with abnormal neutrophil activity. Allergol Immunopathol (Madr). 2000;28(6):328-31.

18. Mason KL, Aronoff DM. Postpartum group A streptococcus sepsis and maternal immunology. Am J Reprod Immunol. 2012;67(2):91-100.

19. Voyich JM, Musser JM, DeLeo FR. Streptococcus pyogenes and human neutrophils: a paradigm for evasion of innate host defense by bacterial pathogens. Microbes Infect. 2004;6(12):1117-23.

20. Cheng $Q$, Stafslien D, Purushothaman SS, Cleary P. The group $B$ streptococcal C5a peptidase is both a specific protease and an invasin. Infect Immun. 2002;70(5):2408-13.

21. Voyich JM, Sturdevant DE, Braughton KR, Kobayashi SD, Lei B, Virtaneva K, et al. Genome-wide protective response used by group A streptococcus to evade destruction by human polymorphonuclear leukocytes. Proc Natl Acad Sci USA. 2003;100(4):1996-2001.

22. Forte WC. Imunologia: do básico ao aplicado. 3a ed. São Paulo: Atheneu; 2015.

23. Dior UP, Kogan L, Elchalal U, Goldschmidt N, Burger A, Nir-Paz R, et al. Leukocyte blood count during early puerperium and its relation to puerperal infection. J Matern Fetal Neonatal Med. 2014;27(1):18-23.

24. Murphy SP, Tayade C, Ashkar AA, Hatta K, Zhang J, Croy BA. Interferon gamma in successful pregnancies. Biol Reprod. 2009;80(5):848-59. 